\title{
Ceramide in the Molecular Mechanisms of Neuronal Cell Death. The Role of Sphingosine-1-Phosphate
}

\author{
Kinga Czubowicz • Robert Strosznajder
}

Received: 22 October 2013 / Accepted: 8 December 2013 /Published online: 14 January 2014

(C) The Author(s) 2014. This article is published with open access at Springerlink.com

\begin{abstract}
Ceramide and sphingosine-1-phosphate (S1P), two important bioactive sphingolipids, have been suggested as being key players in the pathology of Alzheimer's disease in inflammation and cancer. However, their role in the molecular mechanisms of neuronal death has not been fully elucidated. Our study indicated that ceramide significantly enhanced the level of free radicals and decreased the viability of the human neuroblastoma cell line (SH-SY5Y) through inhibition of the prosurvival PI3-K/Akt pathway. Ceramide also decreased anti-apoptotic (Bcl-2) and increased pro-apoptotic (Bax, Hrk) mRNA/protein levels. Concomitantly, our study indicated that ceramide induced poly(ADP-ribose) polymerase-1 (PARP-1) activation and accumulation of poly(ADP-ribose) PAR, a signalling molecule involved in mitochondria-nucleus cross-talk and mitochondria integrity. Ceramide treatment significantly decreased the level of apoptosis-inducing factor (AIF) in the mitochondria. The PARP-1 inhibitor (PJ-34) prevented AIF release from the mitochondria. In addition, our data showed that exogenously added S1P increased the viability of SH-SY5Y through the S1P $(1,3)$ receptordependent mechanism. It was also revealed that the S1P and PARP-1 inhibitor (PJ-34) decreased oxidative stress, gene expression of the pro-apoptotic Hrk protein and up-regulated the anti-apoptotic Bcl-2 protein. Our data demonstrate that neuronal cell death evoked by ceramide is regulated by PARP/PAR/AIF and by S1P receptor signalling. In summary, our results suggest that PARP-1 inhibitor(s) and modulators of sphingosine-1-phosphate receptor(s) should be considered in potential therapeutic strategies directed at neurodegenerative diseases.
\end{abstract}

K. Czubowicz $\cdot$ R. Strosznajder $(\bowtie)$

Laboratory of Preclinical Research and Environmental Agents, Department of Neurosurgery, Mossakowski Medical Research Centre, Polish Academy of Sciences, 5 Pawinskiego Street, 02-106 Warsaw, Poland

e-mail: rstrosznajder@imdik.pan.pl
Keywords Ceramide $\cdot$ S1P $\cdot$ PARP-1 $\cdot$ AIF $\cdot$ SH-SY5Y

\section{Introduction}

Ceramides are a class of sphingolipids that are abundant in cell membranes and play an important role in regulation of the fluidity and structure of the lipid bilayer. During the last decade, ceramides have been recognised as very important second messengers for multiple extracellular stimuli mediating many cellular processes, mainly those associated with the regulation of cell proliferation, differentiation, growth arrest and apoptosis [1-3]. Ceramides are composed of a sphingoid base linked to a fatty acid of varying chain length (14-26 carbons) via an amide bond. Cell-permeable short chain ceramide, C2-ceramide and C6-ceramide have been used in many studies to mimic ceramide-mediated cell death pathways. It was shown that $\mathrm{C} 2$-ceramides were present naturally in the brain at low levels [4]. Treatment of neuronal cells with ceramides at low concentration promotes cell differentiation, survival and neurite outgrowth, while at higher concentration it induces apoptosis. Downstream targets of ceramides are diverse and not completely characterised. It has been described that ceramide regulates mitogen-activated protein kinase (MAPK), protein kinase $\zeta$ (PKC $\zeta$ ), stress-activated protein kinases (SAPK/c-Jun N-terminal kinases (JNK)), ceramide-activated protein kinases (CAPK), ceramideactivated protein phosphatase (CAPP) and phospholipases (cPLA, PLD, PLA 2 ) [5-9]. Ceramides are generated by three metabolic pathways: de novo synthesis, sphingomyelin hydrolysis and the salvage pathway [1]. These pathways are activated in response to oxidative stress, tumour necrosis factor- $\alpha$, chemotherapeutic agents and radiation. Ceramide may be broken down by ceramidases, thus leading to the formation of sphingosine, which can be phosphorylated by sphingosine kinases (Sphk1and Sphk2) to sphingosine-1- 
phosphate (S1P). It is known that S1P acts in an autocrine/ paracrine manner via a family of five S1P-specific cell-surface G-protein-coupled receptors (GPCRs, termed S1P1-5) [10, 11]. S1P signalling through these receptors activates the PI3K/Akt pathway and Ras/extracellular signal-regulated kinases (ERK) to promote proliferation and to prevent apoptosis $[12,13]$. PI3K/Akt regulates many cellular processes including metabolism, proliferation, cell survival, growth and angiogenesis [14]. The balance between the levels of ceramide and S1P, called "ceramide/S1P rheostat", contributes to the fate of the cells [15]. Ceramides, through the formation of channels, have been reported to induct mitochondrial outer membrane permeabilisation, which is a key event in apoptotic signalling [16, 17]. Ceramides affect the activities of the mitochondrial electron transport chain and lead to cellular energy crisis $[18,19]$. This mitochondrial failure evoked by ceramide leads to enhancement of oxidative stress, DNA damage and activation of nuclear enzyme poly(ADP-ribose) polymerase-1 (PARP-1). It was reported previously that the formation of long-chain poly(ADP-ribose) (PAR) and the release of the apoptosis-inducing factor (AIF) from mitochondria to nucleus may accelerate cell death [20-25].

A number of studies have indicated the role of abnormal sphingolipid metabolism in brain ischemia, inflammation, Alzheimer's disease (AD) and other neurodegenerative disorders [26-32]. It was observed in in vivo studies that both a decrease in the S1P level and ceramide accumulation were proportional to the degree of cognitive impairment, loss of intellectual ability and loss of neurons [27, 33, 34]. Ceramides have been indicated as key player in neuronal cell death; however, their role is not yet well understood. It has been demonstrated that neuronal death induced by ceramide may be linked to the caspase-9/caspase-3 regulated intrinsic apoptotic pathway. The data indicated that $\mathrm{C} 2$-ceramide in rat primary cortical neurons induces up-regulation of active caspase- 9 and caspase-3 protein levels $[35,36]$. On the other hand, Kim et al. [37], in human neuroblastoma cell line SY-SY5Y, observed that the inhibition of caspases was not sufficient to attenuated ceramide-induced cell death. Ceramide has been also involved in the control of autophagy [38]. It has been observed that ceramides activate protein phosphatase PP2A, which in turn blocks Akt (activation) the well-known autophagy suppressor [39]. However, the molecular mechanisms of death signalling pathway evoked by ceramide are not fully elucidated. Additionally, the role of exogenous S1P in neuroprotection is still under investigation.

In this study, we investigated the molecular mechanism of neuronal cell death evoked by ceramide focusing on the PI3K/Akt/GSK-3 $\beta$ pathway and on PARP-1/AIF signalling in the human neuroblastoma cell line (SH-SY5Y). The response of pro-apoptotic and anti-apoptotic gene expression was analysed. Moreover, the neuroprotective effect of S1P was evaluated.

\section{Experimental Procedures}

\section{Cell Culture}

The studies were carried out using the human neuroblastoma cell line (SH-SY5Y) (a kind gift from Prof. Anne Eckert, Neurobiology Laboratory for Brain Aging and Mental Health, Psychiatric University Clinics, University of Basel). The SHSY5Y cells were used for experiments between 5 and 15 passage numbers, cultured in MEM/F-12 Ham Nutrient Mixtures $(1: 1)$ supplemented with $15 \%$ heat-inactivated fetal bovine serum (FBS), $1 \%$ penicillin/streptomycin and $2 \mathrm{mM}$ glutamine. Cells were maintained at $37{ }^{\circ} \mathrm{C}$ in a humidified incubator containing $5 \% \mathrm{CO}_{2}$. For the experiment, confluent cells were sub-cultured into dishes or collagen coated 96-well plates. Prior to treatment, the cells were cultivated in low serum $(2 \%$ FBS $)$ medium and then were treated with different inhibitors and compounds.

\section{Cell Treatment Protocols}

SH-SY5Y cells were treated with cell-permeable, biologically active ceramide, $\mathrm{C} 2$-ceramide, at a 10 to $50 \mu \mathrm{M}$ concentration for various times up to $24 \mathrm{~h}$. In most of the experiments, the cells were treated with the following compounds: PJ-34 $(20 \mu \mathrm{M})$, PARP-1 inhibitor; $\alpha$-pifithrin $(20 \mu \mathrm{M})$, p53 inhibitor; cyclosporine A $(2 \mu \mathrm{M})$, inhibitor of the permeability transition pore; UO126 $(1 \mu \mathrm{M})$, ERK1/2 kinase inhibitor; SP600125 $(5 \mu \mathrm{M})$, JNK kinase inhibitor; sphingosine-1phosphate $(1 \mu \mathrm{M})$, LY294002 $(50 \mu \mathrm{M})$, PI3-K inhibitor and Z-DEVD-FMK $(100 \mu \mathrm{M})$, caspase-3 inhibitor added $1 \mathrm{~h}$ before incubation with $\mathrm{C} 2$-ceramide $(25 \mu \mathrm{M})$. Our data showed that most of these compounds had no effect on cell viability in the control condition, with the exception of PARP-1 inhibitor, JNK kinase inhibitor and PI3-K inhibitor, which significantly decreased SH-SY5Y cell survival (by about $20 \%$, PJ-34, SP600125; $35 \%$, LY294002). The above-mentioned compounds were purchased from the following: $\mathrm{C} 2$-ceramide and sphingosine-1-phosphate from Enzo Life Sciences, LY294002 from Cell Signalling Technology, PJ-34, $\alpha-$ pifithrin, SP600125, U0126 and cyclosporine A from Sigma-Aldrich, Z-DEVD-FMK from Tocris Bioscence.

\section{Cell Viability Analysis}

Cell viability and mitochondrial function were evaluated using 2-(4,5-dimethylthiazol-2-yl)-2,5-diphenyltetrazolium bromide (MTT). After $24 \mathrm{~h}$ incubation with $\mathrm{C} 2$-ceramide and selected compounds, MTT was added to all of the wells. The cells were incubated at $37{ }^{\circ} \mathrm{C}$ for $2 \mathrm{~h}$, followed by cell lysis and spectrophotometric measurement at $595 \mathrm{~nm}$. 
Isolation of Cytosolic, Mitochondrial and Nuclear Fractions

Cells were washed and scraped into ice-cold phosphate buffered saline (PBS) and were pelleted at $1,000 \times g$ for $3 \mathrm{~min}$ at $4{ }^{\circ} \mathrm{C}$. The pellet was resuspended in hypotonic buffer $(10 \mathrm{mM}$ Tris-HCl, pH 7.4, $1 \mathrm{mM}$ EDTA, $1 \mathrm{mM}$ EGTA, $1 \mathrm{mM}$ dithiotreitol, $1.5 \mathrm{mM} \mathrm{MgCl} 2,10 \mathrm{mM} \mathrm{KCl}$ and protease inhibitors); cell membranes were disrupted by homogenisation and were pelleted at $500 \times \mathrm{g}$ for $10 \mathrm{~min}$ at $4{ }^{\circ} \mathrm{C}$. The pellet $(\mathrm{P} 1$, the crude nuclear fraction) was resuspended in $25 \mathrm{mM}$ Tris- $\mathrm{HCl} \mathrm{pH} 7.4$ with protease inhibitors and was used for Western blot analysis. A supernatant (S1) was used for isolation of the mitochondria and the cytosolic fraction by centrifugation at $15,000 \times \mathrm{g}$ for $10 \mathrm{~min}$ at $4{ }^{\circ} \mathrm{C}$. The pellet (P2) (crude mitochondria) was resuspended in $25 \mathrm{mM}$ Tris$\mathrm{HCl} \mathrm{pH} 7.4$ with protease inhibitors and was used for Western blot analysis.

\section{Measurement of PARP-1 Activity}

PARP-1 activity was determined using ${ }^{14} \mathrm{C}$-labelled $\beta \mathrm{NAD}^{+}$ as a substrate. The incubation mixture, in a final volume of $100 \mu \mathrm{l}$, contained $200 \mu \mathrm{M}$ (adenine- $\left.{ }^{14} \mathrm{C}\right) \beta \mathrm{NAD}^{+}(4 \times$ $10^{5} \mathrm{dpm}$, Amersham Biosciences), $100 \mathrm{mM}$ Tris- $\mathrm{HCl}$ buffer (pH 8.0), $10 \mathrm{mM} \mathrm{MgCl} 2,5 \mathrm{mM}$ DTT, $50 \mu \mathrm{M} \mathrm{p}$-APMSF and $50-100 \mu \mathrm{g}$ of protein. The mixture was incubated for $1 \mathrm{~min}$ at $37^{\circ} \mathrm{C}$ and the reaction was stopped with $0.8 \mathrm{ml}$ of ice-cold $25 \%$ trichloroacetic acid (TCA). Precipitates were collected on Whatman GF/B filters, washed three times with $5 \%$ TCA and left overnight for drying. The radioactivity was measured using an LKB Wallach 1409 scintillation counter.

\section{Determination of Free Radicals}

The fluorescent 2',7'-dichlorofluorescein (DCF) fluorescence assay detects the level of hydrogen peroxide and other reactive oxygen species (ROS) in cells. Free radicals were determined based on ROS-mediated conversion of $2^{\prime}, 7^{\prime}$-dichlorodihydrofluorescein diacetate (H2DCFDA) into DCF [40, 41]. SH-SY5Y cells were treated with $\mathrm{C} 2$-ceramide and selected inhibitors for $24 \mathrm{~h}$ and then loaded with $10 \mu \mathrm{M}$ H2DCFDA in dimethyl sulfoxide (DMSO) by being incubated for 50 min at $37{ }^{\circ} \mathrm{C}$ in Hank's buffer without Phenol Red (Sigma-Aldrich, St. Louis MO, USA). DMSO was used at a final concentration of $0.05 \%$; at this concentration it had no effect on the free radical levels. Fluorescence of DCF was measured using a Perkin Elmer LS 50B spectrofluorometer with excitation and emission wavelengths at 488 and $535 \mathrm{~nm}$, respectively.
Lactate Dehydrogenase Assay Kit

For the analysis of necrotic cell death, a lactate dehydrogenase (LDH) assay was performed using a commercial LDH cytotoxicity Assay Kit II (BioVision) according to manufacturer's instructions. After $24 \mathrm{~h}$ incubation with C2-ceramide, PJ-34 and S1P cells were centrifuged at $600 \mathrm{~g}$ for $10 \mathrm{~min}$. Next, the clear medium solution was transferred into 96 -well plate. To each well, $100 \mu \mathrm{LDH}$ reaction mix were added. After $30 \mathrm{~min}$ incubation at room temperature, the absorbance at $450 \mathrm{~nm}$ was measured.

Immunochemical Determination of the Protein Level

After protein measurement according to Lowry, the homogenate of SH-SY5Y or the mitochondrial fraction was mixed with $5 \times$ Laemmli sample buffer and denatured for $5 \mathrm{~min}$ at $95^{\circ} \mathrm{C}$. Forty to $60 \mu \mathrm{g}$ of the protein was loaded per lane on $10 \%$ acrylamide gels and examined by sodium dodecyl sulfate (SDS)-polyacrylamide gel electrophoresis. The proteins were transferred onto polyvinylidene difluoride membranes at $100 \mathrm{~V}$. The membranes were incubated in $5 \%$ dry milk in TBS with Tween 20 (TBS-T) for $1 \mathrm{~h}$ and exposed overnight to the following antibodies: anti-AIF (from Santa Cruz Biotechnology, CA, USA), anti-Bcl-2 (from SigmaAldrich, St. Louis, MO, USA), anti-pBad, anti-Bad (from Santa Cruz Biotechnology), anti-GAPDH (from SigmaAldrich), and anti-Actin (from MP Biomedicals. CA, USA). After treatment for $1 \mathrm{~h}$ with corresponding horseradish peroxidase-coupled secondary antibodies (anti-rabbit from Sigma-Aldrich or anti-mouse from Amersham Biosciences), the protein bands were detected by ECL reagent (ThermoScientific). After detection, the membranes were treated with stripping buffer $(50 \mathrm{mM}$ glycine, $\mathrm{pH} 2.5,1 \% \mathrm{SDS}$ ) for further blots.

\section{Analysis of PAR Immunoreactivity}

For the immunochemical detection of PAR formed in vitro, the cells where homogenized in a cold buffer containing $10 \mathrm{mM}$ Tris- $\mathrm{HCl} \mathrm{pH}$ 8.0, $50 \mathrm{mM} \mathrm{NaCl}, 1 \mathrm{mM}$ EDTA, $1 \mathrm{mM}$ DTT and protease inhibitors. The protein homogenate was pre-incubated for $5 \mathrm{~min}$ at $37^{\circ} \mathrm{C}$ and then incubated for $1 \mathrm{~min}$ in the presence of $100 \mathrm{mM}$ Tris- $\mathrm{HCl} \mathrm{pH} 8.0,10 \mathrm{mM}$ $\mathrm{MgCl}_{2}, 5 \mathrm{mM}$ DTT and $0.2 \mathrm{mM} \beta \mathrm{NAD}^{+}$(a blank sample was incubated without $\beta \mathrm{NAD}^{+}$). The reaction was terminated with denaturing sample buffer $\left(5 \mathrm{~min}\right.$ at $\left.95{ }^{\circ} \mathrm{C}\right)$ and the material was subjected to electrophoresis and then transfer as described above. The membrane was blocked in $5 \%$ dry milk and probed with 1:400 anti-PAR antibody (Alexis Corp., clone\#10H) and then with 1:2,000 secondary horseradish peroxidase-linked anti-rabbit IgG. 
The bands were visualised using the ECL kit and the level of PAR was measured densitometrically.

\section{Analysis of the mRNA Level}

RNA was isolated using TRI-reagent from Sigma-Aldrich. The isolated RNA was dissolved in RNAse-free water (Applied Biosystems, Foster City, CA, USA). The amount and purity of RNA was determined using spectrophotometric measurement at 260 and $280 \mathrm{~nm}$. The OD260/OD280 ratio 256 of the RNA samples ranged from 1.6 to 1.9. Isolated RNA $(5 \mu \mathrm{g})$ was used in reverse transcription polymerase chain reaction. Reverse transcription was performed by using a HighCapacity cDNA Reverse Transcription Kit according to the manufacturer's protocol (Applied Biosystems). Quantitative PCR was performed on an ABI PRISM 7500 apparatus by using pre-developed TaqMan Gene Expression Assays (Applied Biosystems): actb Hs99999903_m1; baxHs00180269_ml; bcl2 Hs00608023_m1; hrkHs02621354_s1 according to the manufacturer's instructions. Actb was selected and used in all of the studies as a reference gene. The relative level of mRNA was calculated by the $\Delta \Delta \mathrm{Ct}$ method.

\section{Hoechst Immunostaining}

For morphological studies, SH-SY5Y cells were subjected for $24 \mathrm{~h}$ to oxidative stress evoked by $\mathrm{C} 2$-ceramide together with cytoprotective compounds. Coverslips containing SH-SY5Y cells were collected and washed in PBS. Nuclei were visualised with Hoechst $33342291(0.2 \mu \mathrm{g} / \mathrm{ml}$, Riedel-deHaën Germany) fluorescent staining. The cells were examined under a fluorescence microscope (Olympus BX51, Japan) and photographed with a digital camera (Olympus DP70, Japan).

\section{Statistical Analysis}

Statistical analyses between two groups were conducted using Student's $t$ test. Analyses among multigroup data were conducted using one-way analysis of variance (ANOVA), followed by the Newman-Keuls post hoc test. The data are given as the means \pm SEM. $p$ values $<0.05$ were considered statistically significant.

\section{Results}

SH-SY5Y cells were exposed for $24 \mathrm{~h}$ to cell-permeable C2ceramide. After treatment, cell viability was evaluated by using MTT assay. The addition of C2-ceramide increased the level of free radicals and caused neuronal cell death in a concentration-dependent manner. For further experiments, C2-ceramide at a concentration of $25 \mu \mathrm{M}$ used enhancing oxidative stress by $260 \%$ of the control level and significantly decreasing cell viability by about $60 \%$ (Fig. 1a, b). Our results indicated that the caspase-3 inhibitor (Z-DEVD-FMK) did not attenuate the ceramide-induced SH-SY5Y cell death (data not shown). Signalling through the PI3-K/Akt pathway is critical for cell survival. We observed that $\mathrm{C} 2$-ceramide inactivated the PI3-K/Akt pathway, thus leading to lower phosphorylation of glycogen synthase kinase-beta (GSK3 $\beta$ ) on serine 9, its activation and cell death. Exposure to the PI3-K inhibitor (LY294002) alone or together with C2-ceramide caused SHSY5Y cell death. However, LY294002 did not enhance cell death induced by C2-ceramide (Fig. 2a, b). Oxidative stress can lead to mitochondrial dysfunction and activation of the p53-dependent signalling pathway. Therefore, we investigated the specific inhibitor of p53 ( $\alpha$-pifithrin) and the mitochondrial mega-channel (cyclosporine A). Cyclosporine A and $\alpha$ pifithrin enhanced neuronal cell survival after $\mathrm{C} 2$-ceramide treatment (Fig. 3). These compounds also significantly reduced the level of free radicals (data not shown). Numerous other cytoprotective compounds were also examined in our experimental conditions. The data show that the ERK1/2 inhibitor (U0126) and JNK inhibitor (SP600125) significantly protected the cells against death evoked by $\mathrm{C} 2$-ceramide (Fig. 3). Oxidative stress induced by ceramide can lead to DNA damage and to activation of the nuclear enzyme PARP1. It was observed that C2-ceramide increased PARP-1 activity up to $170 \%$ of the control level (Fig. 4a). In the next step, PAR immunoreactivity was evaluated. Our data demonstrated that $\mathrm{C} 2$-ceramide significantly increased the PAR level (Fig. 4b). Consequently, our data demonstrated that the level of AIF in the mitochondria was decreased (Fig. 4c). This effect was more pronounced in cells treated with $50 \mu \mathrm{M}$ ceramide (data not shown). A specific PARP-1 inhibitor, PJ34, maintained the AIF level in the mitochondria and enhanced cell viability (Fig. 4c, d). We also examined the effect of PJ-34 on ROS production after $24 \mathrm{~h}$ of C2-ceramide treatment. Our results also demonstrated that PARP-1 inhibition significantly reduced the level of free radicals (Fig. 4e). Looking for a novel, promising neuroprotectant, we used in the following study S1P, a product of Sphk1 enzymatic activity, which was expected to activate the pro-survival signalling pathway. Exogenously added S1P at $1 \mu \mathrm{M}$ concentration increased SH-SY5Y cell viability and decreased the ROS level after C2-ceramide treatment (Fig. 5a, b). The question arises as to what are the possible mechanisms by which S1P enhances neuronal cell viability affected by $\mathrm{C} 2$-ceramide. Using a specific receptor antagonist (S1PR1-W123 and S1PR3-VPC23019), it was observed that the neuroprotective effect of S1P was in part receptor-dependent (Fig. 5c). Moreover, in the investigated model, we examined the gene expression/protein level of anti- and pro-apoptotic Bcl-2 proteins. Our data showed that the anti-apoptotic Bcl-2 mRNA level decreased, but that the pro-apoptotic Bax and Hrk mRNA level increased after C2-ceramide treatment. PARP-1 
Fig. 1 The effect of C2-ceramide on SH-SY5Y cell viability (a) and ROS generation (b) after $24 \mathrm{~h}$ incubation. Data represent the mean value \pm SEM for three separate experiments with four to six replications (a) and for three separate experiments with three replications (b). ${ }^{* * *} p<0.001$, ${ }^{* *} p<0.01$ versus control SHSY5Y cells by using one-way ANOVA followed by the Newman-Keuls post hoc test

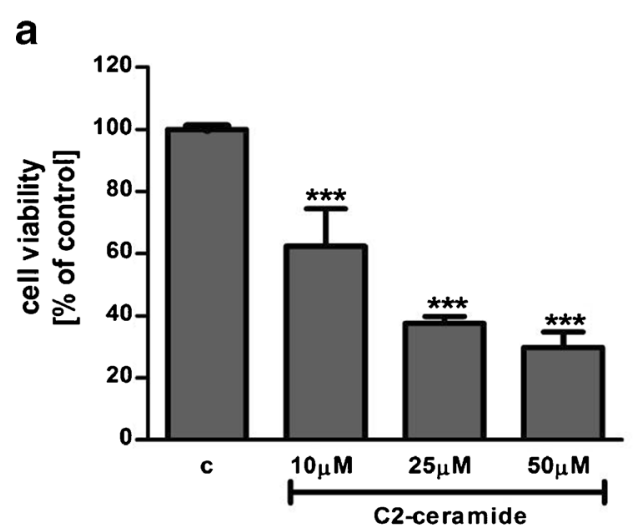

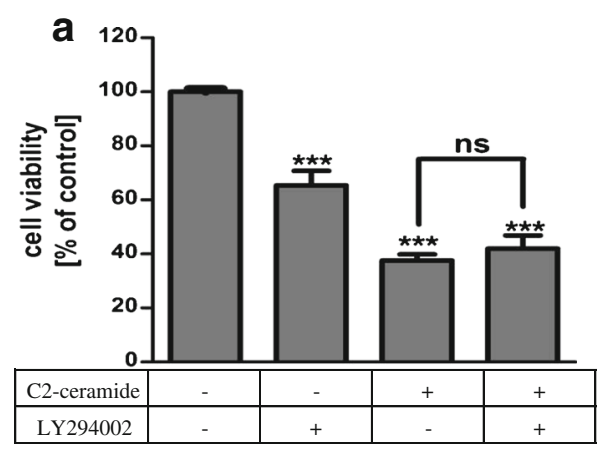
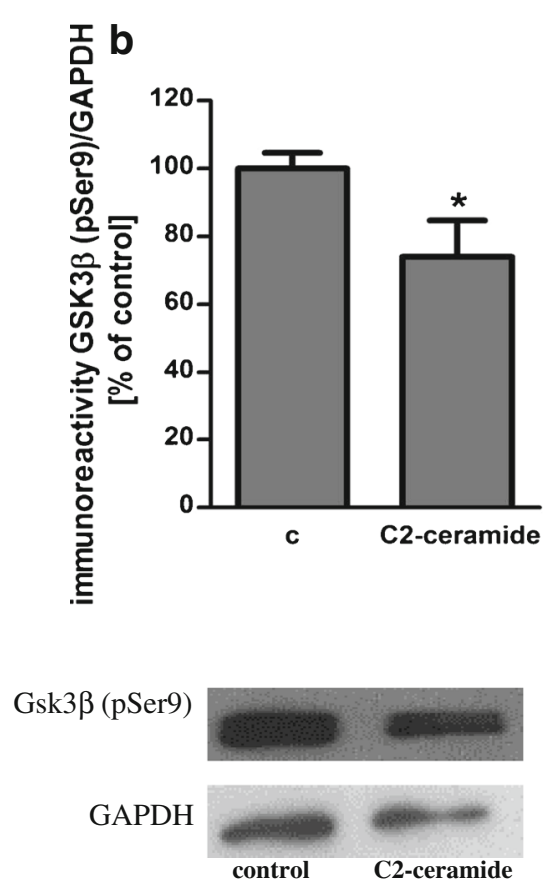

Fig. 2 The effect of PI3-K kinase inhibitor (LY294002 $\{50 \mu \mathrm{M}\}$ ) on SHSY5Y cell viability under oxidative stress evoked by $\mathrm{C} 2$-ceramide $(25 \mu \mathrm{M}, 24 \mathrm{~h})(\mathbf{a})$. Data represent the mean value \pm SEM for three separate experiments with four to six replications. ${ }^{* *} p<0.001$ versus control $\mathrm{SH}-$ SY5Y cells by using one-way ANOVA followed by the Newman-Keuls post hoc test. The effect of C2-ceramide $(25 \mu \mathrm{M}, 24 \mathrm{~h})$ on the level of GSK3 $\beta$ (pSer 9) immunoreactivity (b). Data represent the mean value \pm SEM for three separate experiments normalised against GAPDH. Representative Western blots from one typical experiment are shown below the graphs. ${ }^{*} p<0.0452$ versus control SH-SY5Y cells by Student's $t$ test

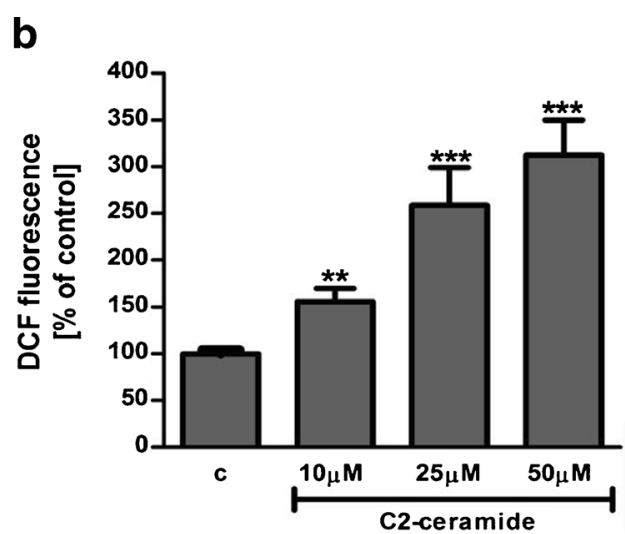

inhibition and exogenously added S1P enhanced the Bcl-2 mRNA/protein level and decreased the Hrk mRNA level affected by ceramide. However, PJ-34 and S1P had no effect on the Bax mRNA level (Fig. 6a-c). We also observed that $\mathrm{C} 2$-ceramide decreased the level of the $\mathrm{Bcl}-2$ protein and induced dephosphorylation of the pro-apoptotic Bad protein on Ser136, which was reversed by PARP-1 inhibition (Fig. 7a, b). For evaluation of apoptotic cell death, microscopic examination of cell nuclei stained with DNA-binding fluorochrome Hoechst 33342 was used. The data showed that SHSY5Y cells exposed to C2-ceramide presented apoptotic morphology, i.e. condensation of chromatin and nuclear fragmentation. The protective effect of PJ-34 and S1P was observed (Fig. 8). It is worth to underline that $\mathrm{C} 2$-ceramide significantly increased LDH release. However, we have

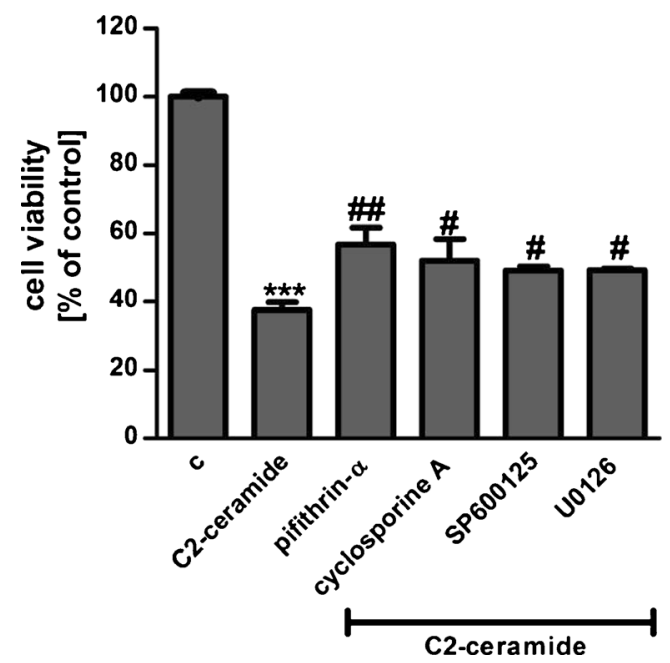

Fig. 3 Evaluation of selected molecular events in neuronal cell (SH-SY5Y) death evoked by C2-ceramide $(25 \mu \mathrm{M}, 24 \mathrm{~h})$. The following specific inhibitors were used: $\alpha$-pifithrin $(20 \mu \mathrm{M})$, p53 inhibitor; cyclosporine $\mathrm{A}(2 \mu \mathrm{M})$, inhibitor of the mitochondrial permeability transition pore; UO126 $(1 \mu \mathrm{M})$, inhibitor of ERK1/2 kinases; and SP600125 $(5 \mu \mathrm{M})$, JNK kinase inhibitor. Data represent the mean value \pm SEM for three separate experiments with four to six replications. ${ }^{* * *} p<0.001$ versus control SH-SY5Y cells, ${ }^{\# \#} p<0.001,{ }^{\# \#} p<0.01,{ }^{\#} p<0.05$ versus C2-ceramide treated SH-SY5Y cells by using one-way ANOVA followed by the Newman-Keuls post hoc test 
not found any protective effect of PJ-34 and S1P (data not shown).

\section{Discussion}

In our current study, the mechanism of ceramide-evoked neuronal death was analysed. Moreover, the effect of exogenous S1P in molecular alterations induced by ceramide in neuronal cells SH-SY5Y was evaluated. We demonstrated that $\mathrm{C} 2$-ceramide, through inhibition of PI3K/Akt, influenced the phosphorylation state of GSK $3 \beta$ and Bad. Neuronal cell death evoked by ceramide is probably connected with PI3K/Akt inhibition, which was demonstrated by us using the PI3K inhibitor. These observations are consistent with a previous study on SH-SY5Y cells [37]. It was also reported that the Akt pathway is down-regulated by $\mathrm{C} 2$-ceramide in the

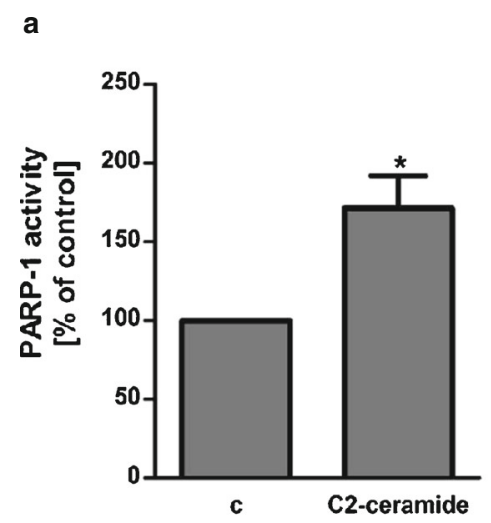

Fig. 4 The role of PARP-1 in ceramide toxicity. PARP-1 activity and its role in oxidative stress and neuronal cell death evoked by $\mathrm{C} 2$-ceramide $(25 \mu \mathrm{M}, 24 \mathrm{~h})(\mathbf{a})$. Data represent the mean value \pm SEM for three separate experiments with three replications. ${ }^{*} p<0.0367$ versus control SH-SY5Y cells by Student's $t$ test. The effect of C2-ceramide $(25 \mu \mathrm{M}, 12 \mathrm{~h})$ on PAR immunoreactivity in SH-SY5Y cells (b). Data represent the mean value \pm SEM for three separate experiments normalised against GAPDH. Representative Western blots from one typical experiment are shown below the graphs. ${ }^{*} p<0.0419$ versus control SH-SY5Y cells by Student's $t$ test. The effect of PARP-1 inhibitor (PJ-34 $\{20 \mu \mathrm{M}\}$ ) on AIF immunoreactivity in the mitochondrial fraction of SH-SY5Y cells after $\mathrm{C} 2$-ceramide treatment $(25 \mu \mathrm{M}, 12 \mathrm{~h})(\mathbf{c})$. Representative Western blots from one typical
NGF-treated PC12 cells as a result of enhanced dephosphorylation of Akt1 by protein phosphatase (CAPP-PP2A) [42]. It is known that Akt phosphorylates and inactivates the proapoptotic Bad protein. This process can contribute to stabilisation of the mitochondrial membrane. It has been previously reported that PARP-1 inhibition induced Akt phosphorylation and activation [43]. Our study showed that PARP-1 inhibition reversed the effect of $\mathrm{C} 2$ ceramide on Bad phosphorylation probably due to Akt activation.

Ceramide can exert its effect by modulation of lipid kinases, e.g. JNK [44, 45]. A correlation between increased ceramide level and JNK activation via phosphorylation has been reported in differentiated PC-12 cells [46]. JNK activation and its nuclear translocation in neurons have been reported in vivo in several pathological conditions [44]. The potential target of pro-apoptotic signalling by JNK is the

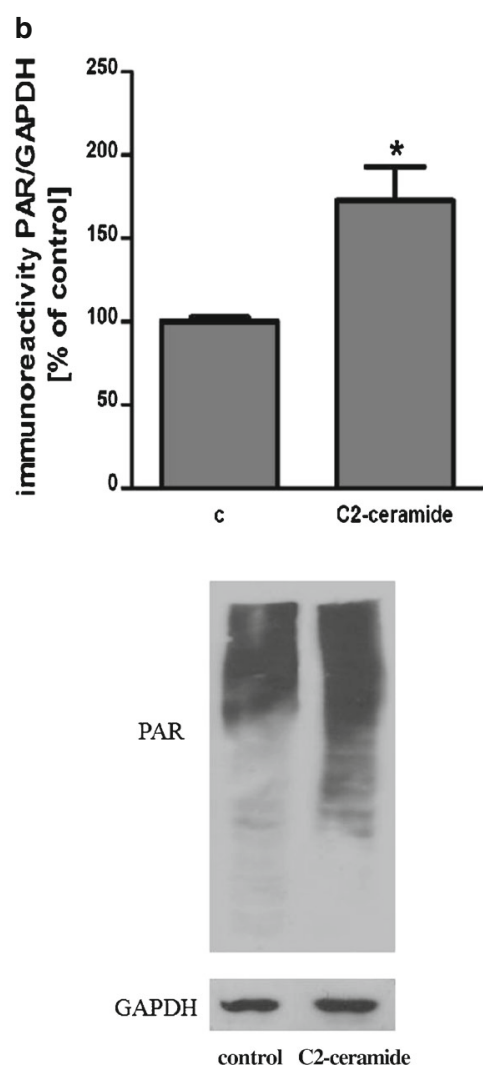

experiment are shown below the graphs. Data represent the mean value \pm SEM for three independent experiments normalised against $\beta$-actin. ${ }^{*} p<0.05$ versus control SH-SY5Y cells, ${ }^{\# \#} p<0.01$ versus C2-ceramide treated SH-SY5Y cells by using one-way ANOVA followed by the Newman-Keuls post hoc test. The effect of PARP-1 inhibitor (PJ-34 $\{20 \mu \mathrm{M}\}$ ) on SH-SY5Y cell viability (d) and ROS generation (e) after incubation with C2-ceramide $(25 \mu \mathrm{M}, 24 \mathrm{~h})$. Data represent the mean value \pm SEM for three separate experiments with four to six replications (d) and for three separate experiments with three replications (e). ${ }^{* * *} p<0.001$ versus control SH-SY 5 Y cells, ${ }^{\# \#} p<0.001,{ }^{\# \#} p<0.01$ versus C2-ceramide treated SH-SY5Y cells by using one-way ANOVA followed by the Newman-Keuls post hoc test 
transcription factor c-Jun. An increase of c-Jun phosphorylation was found in neuronal nuclei after ceramide treatment [8]. Our results demonstrated that the inhibition of JNK had a small but statistically significant effect on cell viability in this stress condition. It has been reported that the JNK signalling pathway can mediate apoptosis by regulating the expression of pro-apoptotic Bcl-2 family proteins [47, 48]. Moreover, Chen et al. [49] demonstrated that amyloid beta peptides $(A \beta)$, by activation of neutral sphingomyelinase and ceramide generation, may up-regulate death protein 5 (DP5/Hrkharakiri) via JNK action. They observed that the both $A \beta$ and $\mathrm{C} 2$-ceramide rapidly induced Hrk gene expression, increased JNK phosphorylation and AP-1 DNA binding. It is known that AP-1 DNA-binding consensus sequences are present in the promoter region of DP5/Hrk. Our finding that C2-ceramide up-regulated Hrk gene expression is in agreement with this study. Hrk was originally identified as a proapoptotic gene located at 12q13.1 [50,51]. The role of Hrk in apoptosis has been described mainly in hematopoietic tissues and cultured neurons [51, 52]. It has been observed that Hrk interacts with the anti-apoptotic proteins $\mathrm{Bcl}-2$ and $\mathrm{Bcl}-\mathrm{X}_{\mathrm{L}}$, but not with pro-apoptotic Bax or Bak [53] and that apoptosis by Hrk required the expression of Bax [52]. We provided evidence, for the first time, that PARP-1 inhibition reduced the mRNA level of Hrk after C2-ceramide treatment. Recent data have demonstrated that PARP inhibitors induced the suppression of JNK in vitro and in vivo $[54,55]$. Therefore, it can be inferred that the effect of the PARP-1 inhibitor (PJ34) on Hrk gene expression is associated with the attenuation of JNK activation. We demonstrated that $\mathrm{C} 2$-ceramide induced production of reactive oxygen species in a concentration-dependent manner. It is known that DNA damage caused by oxidative stress may activate PARP-1, a key nuclear enzyme involved in DNA repair. Our results showed PARP-1 activation and PAR polymer formation after C2ceramide treatment. Upon activation, PARP-1 transforms nicotinamide adenine dinucleotide (NAD+) into long PAR polymers and transfers them to a variety of nuclear proteins, e.g. histones, DNA polymerases and PARP-1 itself [21, 56-59]. The basal levels of PAR are very low; however, excessive
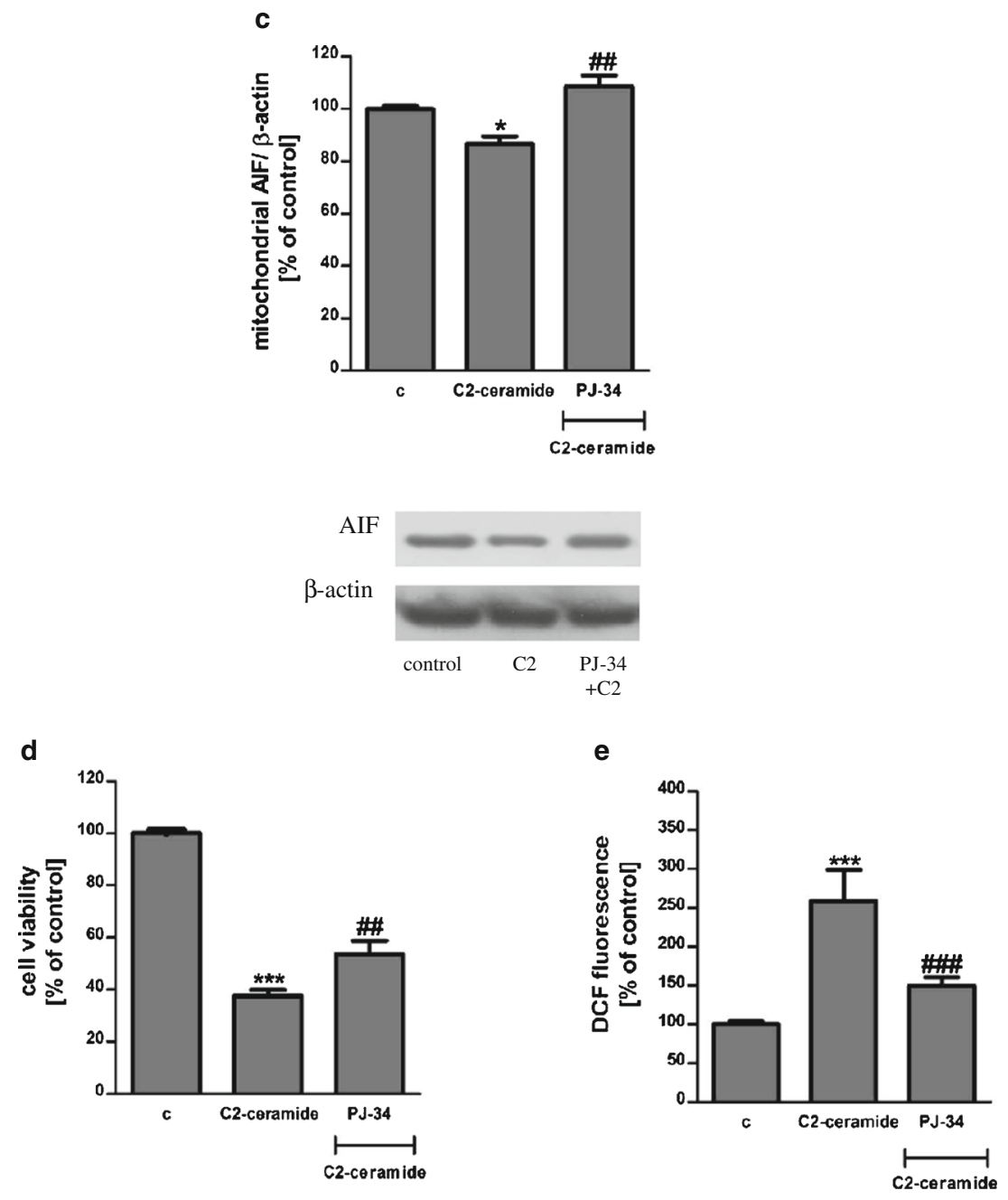

e

Fig. 4 continued. 
Fig. 5 The effect of sphingosine1-phosphate (S1P $\{1 \mu \mathrm{M}\})$ on SH-SY5Y cell viability (a) and ROS generation (b) after incubation with $\mathrm{C} 2$-ceramide (25 $\mu \mathrm{M}, 24 \mathrm{~h})$. Data represent the mean value \pm SEM for three separate experiments with four to six replications (a) and for three separate experiments with three replications (b). The effect of S1P receptor antagonists (S1PR1$\mathrm{W} 123\{20 \mu \mathrm{M}\}$ and S1PR3VPC23019 $\{1 \mu \mathrm{M}\})$ on SHSY5Y cell viability after C2ceramide treatment $(25 \mu \mathrm{M}, 24 \mathrm{~h})$ (c). ${ }^{* * *} p<0.001$ versus control SH-SY5Y cells, ${ }^{\# \# \# ~} p<0.001$ versus $\mathrm{C} 2$-ceramide treated $\mathrm{SH}$ SY5Y cells, ${ }^{\$ \$} \$<0.001$ versus C2-ceramide and S1P treated SHSY5Y cells by using one-way ANOVA followed by the Newman-Keuls post hoc test
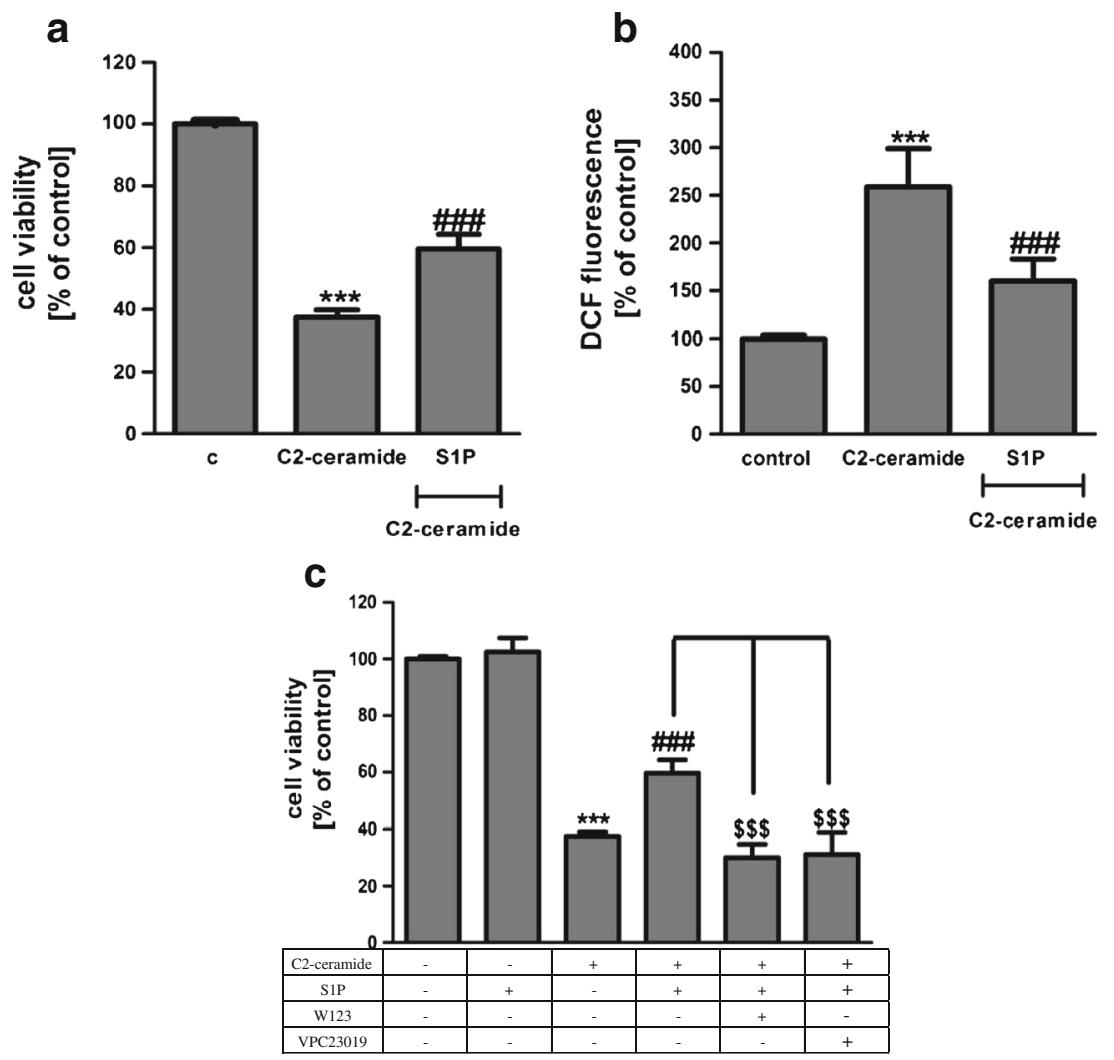

activation of PARP-1 leads to a 10- to 500-fold increase in PAR polymer formation. The PAR polymer participates directly in cell death signalling. PAR is responsible for mitochondrial AIF release and caspase-independent apoptosis [21,
57, 58, 60]. The proper AIF level in mitochondria is very important for the integration of proteins of electron transport complexes. AIF is proposed to regulate the respiratory chain indirectly, through assembly and/or stabilisation of complexes
Fig. $6 \mathrm{Bcl}-2$ protein family expression in SH-SY5Y cells subjected to oxidative stress. mRNA levels for Bcl-2 (a), Hrk (b) and Bax (c) were evaluated using real-time PCR after incubation with $\mathrm{C} 2$-ceramide ( $25 \mu \mathrm{M}, 3 \mathrm{~h})$. The value expresses the fold of gene stimulation normalised against Actb

$(\beta$-actin). Data represent the mean value \pm SEM for three separate experiments with three replications. ${ }^{*} p<0.01,{ }^{*} p<0.05$ versus control SH-SY5Y cells, ${ }^{\#} p<0.01,{ }^{\#} p<0.05$ versus C2ceramide treated SH-SY5Y cells by using one-way ANOVA followed by the Newman-Keuls post hoc test
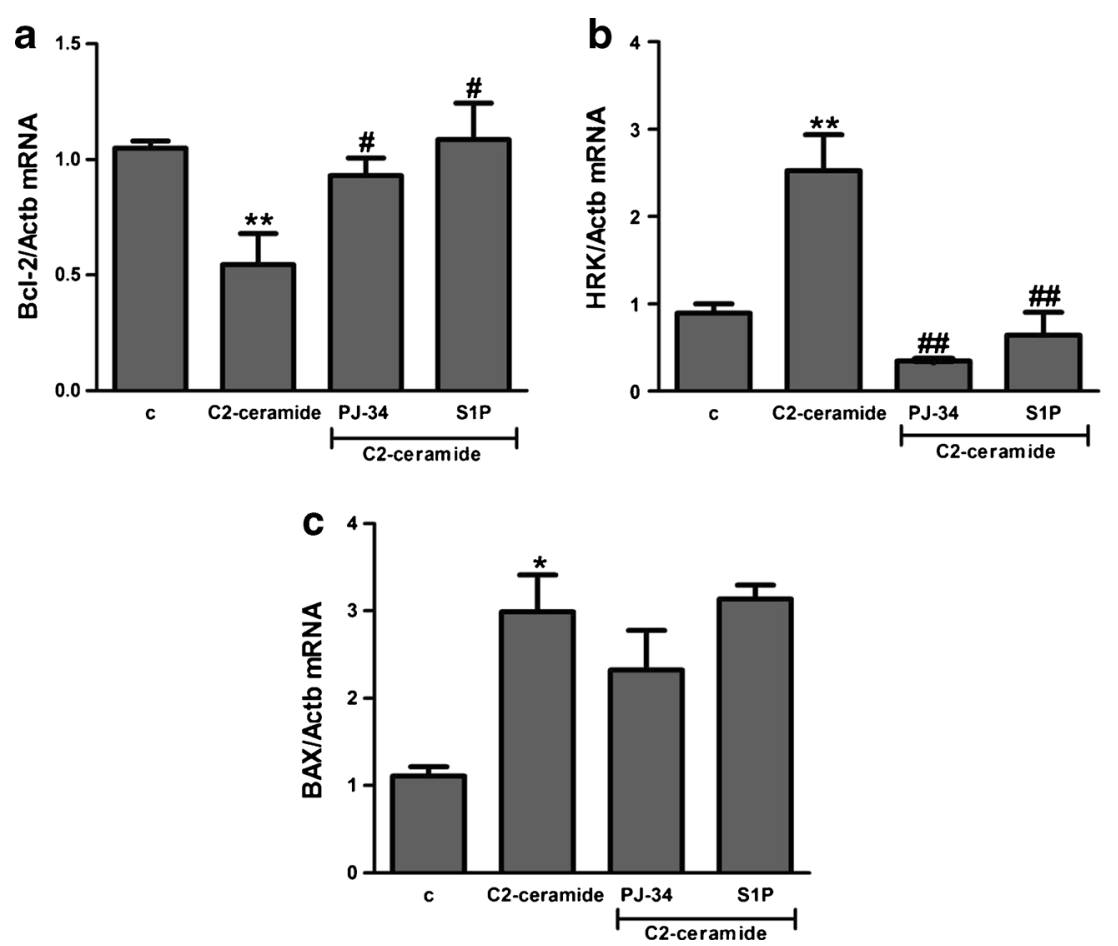
I and III [61-63]. The reduction in assembled complex I associated with AIF deficiency is anticipated to have a profound effect on mitochondrial function in neurons [64]. However, we ought to keep in mind that AIF after translocation to nucleus exerted endonuclease activity and is responsible for the DNA degradation into $50 \mathrm{~kb}$ fragments [65]. Our data indicated that $\mathrm{C} 2$-ceramide caused the AIF release from mitochondria, which was also observed in other experimental conditions by [21-23, 37, 60, 65]. Our study showed that PARP-1 inhibition significantly protected SH-SY5Y against ceramide-induced cell death by reducing the level of ROS production, thus preventing the AIF release from the mitochondria and increasing the mRNA level of anti-apoptotic Bcl-2. Moreover, we observed enhancement of Bad phosphorylation and down-regulation of Hrk gene expression. A previous study by Kauppinen et al. [66] showed that pharmacological inhibition of ERK1/2 prevented PARP-1 activation and reduced PARP-1-mediated neuronal death. Our results demonstrated that the inhibition of ERK1/2 kinases had a small but statistically significant effect on cell viability. Because it is postulated that ceramide and S1P play a crucial role in cell survival and death, the effect of exogenous S1P was evaluated. It has been observed that S1P $(1 \mu \mathrm{M})$ exerts its inhibitory effect on apoptosis through members of the Bcl-2 protein family and the reduction of oxidative stress. The present findings implicate a decrease in the mRNA level of the pro-apoptotic (Hrk) proteins and an increase in the mRNA/protein level of anti-apoptotic (Bcl-2) Bcl-2 proteins as one of the mechanisms through which S1P protects SHSY5Y cells from apoptosis. These data are consistent with studies on other cell types. It has been observed that exogenous S1P regulates the expression of pro-apoptotic and antiapoptotic proteins; e.g. exogenous S1P increases the expression of the anti-apoptotic Bcl-2 [67] and Mcl-1 [68] while it down-regulates the pro-apoptotic proteins Bad and Bax [69]. Exogenous S1P also blocks the translocation of Bax to the
Fig. 7 The effect of PARP-1 inhibitor (PJ-34 $\{20 \mu \mathrm{M}\})$ and $\mathrm{S} 1 \mathrm{P}(1 \mu \mathrm{M})$ on the Bcl-2 (a), $\mathrm{pBad}(\mathrm{Ser} 136)$ and Bad (b) protein level after incubation with C2-ceramide $(25 \mu \mathrm{M}, 24 \mathrm{~h})$. Data represent the mean value \pm SEM for three separate experiments normalised against GAPDH. Representative Western blots from one typical experiment are shown below the graphs. ${ }^{*} p<0.05$ versus control SH-SY5Y cells, ${ }^{\# \#} p<0.01,{ }^{\#} p<0.05$ versus C2ceramide treated $\mathrm{SH}-\mathrm{SY} 5 \mathrm{Y}$ cells by using one-way ANOVA followed by the Newman-Keuls post hoc test a

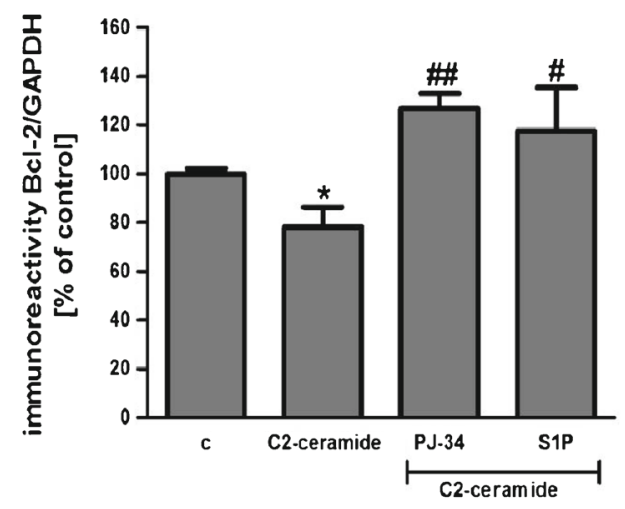

Bcl-2

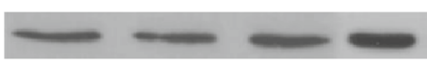

GAPDH

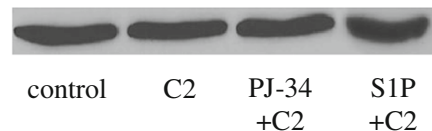

b

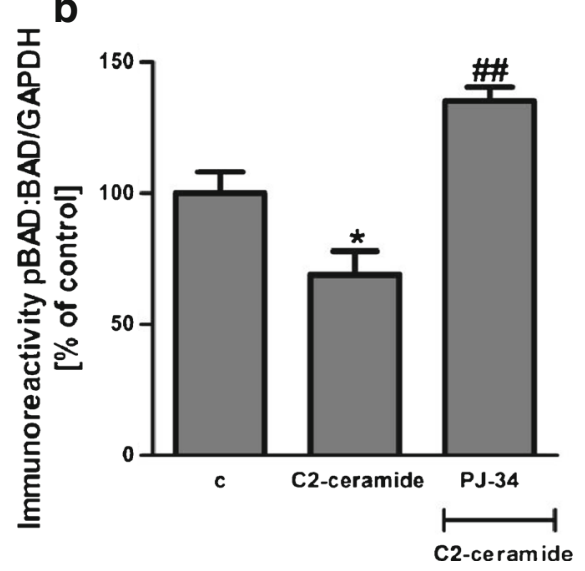

pBAD

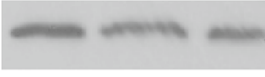

GAPDH

BAD

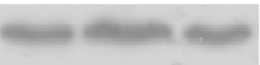

GAPDH

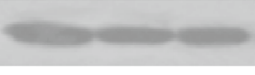

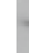
control $\quad \mathrm{C} 2 \quad \mathrm{PJ}-34$ 
a

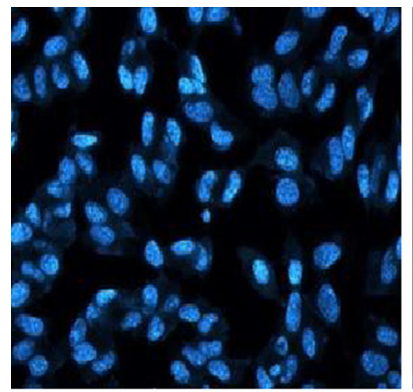

control
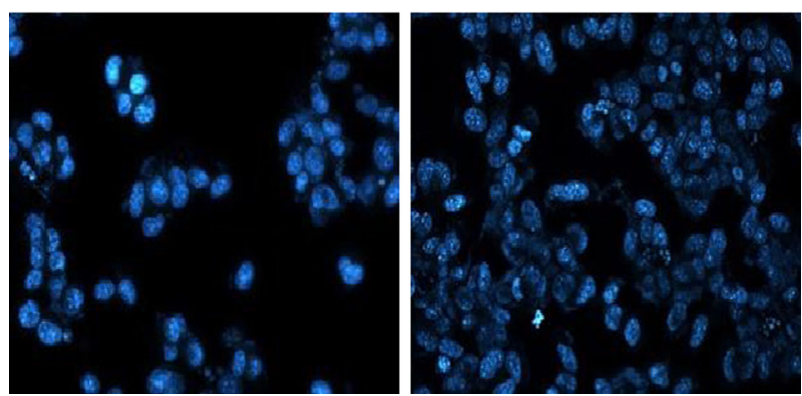

PJ-34 + C2-ceramide S1P + C2-ceramide

b

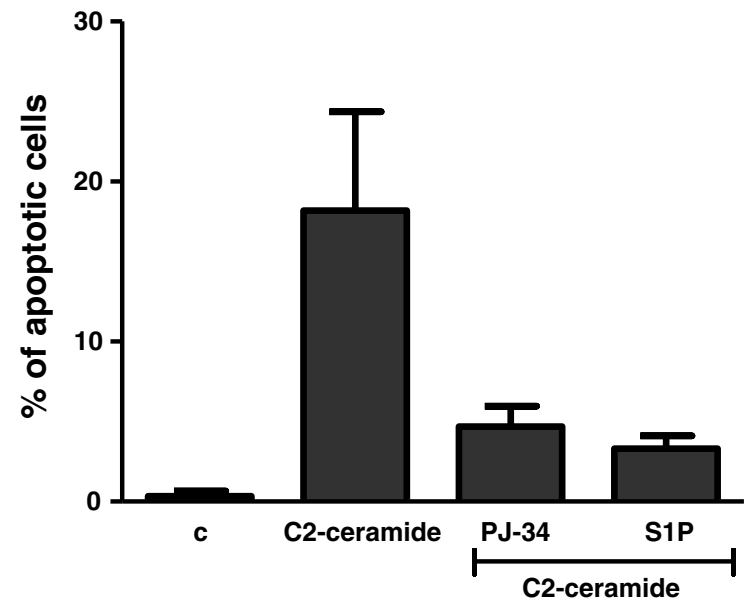

Fig. 8 Microscopic examination of cell nuclei, stained with DNA-binding fluorochrome Hoechst 33342. The cells were treated with PARP-1 inhibitor (PJ-34 $\{20 \mu \mathrm{M}\})$, sphingosine-1-phosphate $(1 \mu \mathrm{M})$ and then with $\mathrm{C} 2$-ceramide $(25 \mu \mathrm{M})$ (a). Cells with typical apoptotic nuclear morphology (nuclear shrinkage, chromatin condensation) were identified and counted. The results were expressed as percentages of apoptotic cells in the whole cell population from one exemplary experiment in four to eight replications (b)

mitochondria [70]. Our study with specific S1P receptor antagonists revealed that the pro-survival signal of S1P was mainly dependent on S1PR1 and S1PR3 receptors. S1P signalling through these receptors may induce the activation of the PI3K/Akt pathway $[12,13,71]$. It has been observed that the activation of Akt can inhibit apoptosis by blocking the release of AIF from the mitochondria [37]. Our data indicate that such events as: activation of PARP-1, accumulation of PAR and alteration of AIF level in mitochondria play a significant role in the mechanism of apoptotic caspase-3 independent cells death. As a conclusive remark, we suggest that the modulators of sphingosine-1-phosphate receptor(s) and PARP-1 inhibitor(s) should be considered in the therapy of neurodegenerative disorders.

Acknowledgments The study was supported by the statutory budget of MRC theme nr 1 and NCN grant 5870/P01/2011/40.

Open Access This article is distributed under the terms of the Creative Commons Attribution License which permits any use, distribution, and reproduction in any medium, provided the original author(s) and the source are credited.

\section{References}

1. Hannun YA, Obeid LM (2008) Principles of bioactive lipid signalling: lessons from sphingolipids. Nat Rev Mol Cell Biol 9:139-150

2. Mencarelli C, Martinez-Martinez P (2013) Ceramide function in the brain: when a slight tilt is enough. Cell Mol Life Sci 70:181-203

3. Morad SA, Cabot MC (2013) Ceramide-orchestrated signalling in cancer cells. Nat Rev Cancer 13:51-65

4. Van Overloop H, Denizot Y, Baes M, Van Veldhoven PP (2007) On the presence of $\mathrm{C} 2$-ceramide in mammalian tissues: possible relationship to etherphospholipids and phosphorylation by ceramide kinase. Biol Chem 388:315-324

5. Dobrowsky RT, Kamibayashi C, Mumby MC, Hannun YA (1993) Ceramide activates heterotrimeric protein phosphatase 2A. J Biol Chem 268:15523-15530

6. Lozano J, Berra E, Municio MM, Diaz-Meco MT, Dominguez I, Sanz L, Moscat J (1994) Protein kinase C zeta isoform is critical for kappa B-dependent promoter activation by sphingomyelinase. J Biol Chem 269:19200-19202

7. Lee JY, Hannun YA, Obeid LM (1996) Ceramide inactivates cellular protein kinase C alpha. J Biol Chem 271:13169-13174

8. Willaime-Morawek S, Brami-Cherrier K, Mariani J, Caboche J, Brugg B (2003) C-Jun N-terminal kinases/c-Jun and p38 pathways cooperate in ceramide-induced neuronal apoptosis. Neuroscience 119:387-397

9. Arboleda G, Cárdenas Y, Rodríguez Y, Morales LC, Matheus L, Arboleda H (2010) Differential regulation of AKT, MAPK and GSK3 $\beta$ during C2-ceramide-induced neuronal death. Neurotoxicology 31:687-693

10. Sanchez T, Hla T (2004) Structural and functional characteristics of S1P receptors. J Cell Biochem 92:913-922

11. Strub GM, Maceyka M, Hait NC, Milstien S, Spiegel S (2010) Extracellular and intracellular actions of sphingosine-1-phosphate. Adv Exp Med Biol 688:141-155

12. Obinata H, Hla T (2012) Sphingosine 1-phosphate in coagulation and inflammation. Semin Immunopathol 34:73-91

13. Maceyka M, Harikumar KB, Milstien S, Spiegel S (2012) Sphingosine-1-phosphate signaling and its role in disease. Trends Cell Biol 22:50-60

14. Hers I, Vincent EE, Tavaré JM (2011) Akt signalling in health and disease. Cell Signal 23:1515-1527

15. Cuvillier O, Pirianov G, Kleuser B, Vanek PG, Coso OA, Gutkind S, Spiegel S (1996) Suppression of ceramide-mediated programmed cell death by sphingosine-1-phosphate. Nature 381:800-803 
16. Siskind LJ, Kolesnick RN, Colombini M (2002) Ceramide channels increase the permeability of the mitochondrial outer membrane to small proteins. J Biol Chem 277:26796-26803

17. Ganesan V, Perera MN, Colombini D, Datskovskiy D, Chadha K, Colombini M (2010) Ceramide and activated Bax act synergistically to permeabilize the mitochondrial outer membrane. Apoptosis 15 : 553-562

18. Gudz TI, Tserng KY, Hoppel CL (1997) Direct inhibition of mitochondrial respiratory chain complex III by cell-permeable ceramide. J Biol Chem 272:24154-24158

19. Kogot-Levin A, Saada A (2013) Ceramide and the mitochondrial respiratory chain. Biochimie. doi:10.1016/j.biochi.2013.07.027

20. Yu SW, Andrabi SA, Wang H, Kim NS, Poirier GG, Dawson TM, Dawson VL (2006) Apoptosis-inducing factor mediates poly(ADPribose) (PAR) polymer-induced cell death. Proc Natl Acad Sci U S A 103:18314-18319

21. Cieslik M, Pyszko J, Strosznajder JB (2013) Docosahexaenoic acid and tetracyclines as promising neuroprotective compounds with poly(ADP-ribose) polymerase inhibitory activities for oxidative/ genotoxic stress treatment. Neurochem Int 62:626-636

22. Strosznajder RP, Gadamski R, Czapski GA, Jesko H, Strosznajder JB (2003) Poly(ADP-ribose) polymerase during reperfusion after transient forebrain ischemia: its role in brain edema and cell death. J Mol Neurosci 20:61-72

23. Strosznajder RP, Jesko H, Adamczyk A (2005) Effect of aging and oxidative/genotoxic stress on poly(ADP-ribose) polymerase-1 activity in rat brain. Acta Biochim Pol 52:909-914

24. Strosznajder RP, Gajkowska B (2006) Effect of 3-aminobenzamide on Bcl-2, Bax and AIF localization in hippocampal neurons altered by ischemia-reperfusion injury. The immunocytochemical study. Acta Neurobiol Exp (Wars) 66:15-22

25. Czapski GA, Adamczyk A, Strosznajder RP, Strosznajder JB (2013) Expression and activity of PARP family members in the hippocampus during systemic inflammation: their role in the regulation of prooxidative genes. Neurochem Int 62:664-673

26. Jana A, Hogan EL, Pahan K (2009) Ceramide and neurodegeneration: susceptibility of neurons and oligodendrocytes to cell damage and death. J Neurol Sci 278:5-15

27. Haughey NJ, Bandaru VV, Bae M, Mattson MP (2010) Roles for dysfunctional sphingolipid metabolism in Alzheimer's disease neuropathogenesis. Biochim Biophys Acta 1801:878-886

28. Ohtani R, Tomimoto H, Kondo T, Wakita H, Akiguchi I, Shibasaki $\mathrm{H}$, Okazaki T (2004) Upregulation of ceramide and its regulating mechanism in a rat model of chronic cerebral ischemia. Brain Res 1023:31-40

29. Yu J, Novgorodov SA, Chudakova D, Zhu H, Bielawska A, Bielawski J, Obeid LM, Kindy MS, Gudz TI (2007) JNK3 signaling pathway activates ceramide synthase leading to mitochondrial dysfunction. J Biol Chem 282:25940-25949

30. Agudo-López A, Miguel BG, Fernández I, Martínez AM (2010) Involvement of mitochondria on neuroprotective effect of sphingosine-1-phosphate in cell death in an in vitro model of brain ischemia. Neurosci Lett 470:130-133

31. Kim S, Steelman AJ, Zhang Y, Kinney HC, Li J (2012) Aberrant upregulation of astroglial ceramide potentiates oligodendrocyte injury. Brain Pathol 22:41-57

32. Singh I, Pahan K, Khan M, Singh AK (1998) Cytokine-mediated induction of ceramide production is redox-sensitive. Implications to proinflammatory cytokine-mediated apoptosis in demyelinating diseases. J Biol Chem 273:20354-20362

33. He X, Huang Y, Li B, Gong CX, Schuchman EH (2010) Deregulation of sphingolipid metabolism in Alzheimer's disease. Neurobiol Aging 31:398-408

34. Katsel P, Li C, Haroutunian V (2007) Gene expression alterations in the sphingolipid metabolism pathways during progression of dementia and Alzheimer's disease: a shift toward ceramide accumulation at the earliest recognizable stages of Alzheimer's disease? Neurochem Res 32:845-856

35. Stoica BA, Movsesyan VA, Lea PM 4th, Faden AI (2003) Ceramideinduced neuronal apoptosis is associated with dephosphorylation of Akt, BAD, FKHR, GSK-3beta, and induction of the mitochondrialdependent intrinsic caspase pathway. Mol Cell Neurosci 22:365-382

36. Movsesyan VA, Yakovlev AG, Dabaghyan EA, Stoica BA, Faden AI (2002) Ceramide induces neuronal apoptosis through the caspase-9/ caspase-3 pathway. Biochem Biophys Res Commun 299:201-207

37. Kim NH, Kim K, Park WS, Son HS, Bae Y (2007) PKB/Akt inhibits ceramide-induced apoptosis in neuroblastoma cells by blocking apoptosis-inducing factor (AIF) translocation. J Cell Biochem 102: $1160-1170$

38. Young MM, Kester M, Wang HG (2013) Sphingolipids: regulators of crosstalk between apoptosis and autophagy. J Lipid Res 54:5-19

39. Scarlatti F, Bauvy C, Ventruti A, Sala G, Cluzeaud F, Vandewalle A, Ghidoni R, Codogno P (2004) Ceramide-mediated macroautophagy involves inhibition of protein kinase B and up-regulation of beclin 1 . J Biol Chem 279:18384-18391

40. Royall JA, Ischiropoulos H (1993) Evaluation of 2', 7'-dichlorofluorescin and dihydrorhodamine 123 as fluorescent probes for intracellular $\mathrm{H} 2 \mathrm{O} 2$ in cultured endothelial cells. Arch Biochem Biophys 302:348-355

41. Kazmierczak A, Strosznajder JB, Adamczyk A (2008) alphaSynuclein enhances secretion and toxicity of amyloid beta peptides in PC12 cells. Neurochem Int 53:263-269

42. Salinas M, López-Valdaliso R, Martín D, Alvarez A, Cuadrado A (2000) Inhibition of PKB/Akt1 by C2-ceramide involves activation of ceramide-activated protein phosphatase in PC12 cells. Mol Cell Neurosci 15:156-169

43. Tapodi A, Debreceni B, Hanto K, Bognar Z, Wittmann I, Gallyas F Jr, Varbiro G, Sumegi B (2005) Pivotal role of Akt activation in mitochondrial protection and cell survival by poly(ADPribose)polymerase-1 inhibition in oxidative stress. J Biol Chem 280:35767-35775

44. Harper SJ, LoGrasso P (2001) Signalling for survival and death in neurones: the role of stress-activated kinases, JNK and p38. Cell Signal 13:299-310

45. Borsello T, Forloni G (2007) JNK signalling: a possible target to prevent neurodegeneration. Curr Pharm Des 13:1875-1886

46. Soeda S, Tsuji Y, Ochiai T, Mishima K, Iwasaki K, Fujiwara M, Yokomatsu T, Murano T, Shibuya S, Shimeno H (2004) Inhibition of sphingomyelinase activity helps to prevent neuron death caused by ischemic stress. Neurochem Int 45:619-626

47. Lei K, Davis RJ (2003) JNK phosphorylation of Bim-related members of the Bcl2 family induces Bax-dependent apoptosis. Proc Natl Acad Sci U S A 100:2432-2437

48. Lei K, Nimnual A, Zong WX, Kennedy NJ, Flavell RA, Thompson CB, Bar-Sagi D, Davis RJ (2002) The Bax subfamily of Bcl2-related proteins is essential for apoptotic signal transduction by c-Jun NH(2)terminal kinase. Mol Cell Biol 22:4929-4942

49. Chen S, Lee JM, Zeng C, Chen H, Hsu CY, Xu J (2006) Amyloid beta peptide increases DP5 expression via activation of neutral sphingomyelinase and JNK in oligodendrocytes. J Neurochem 97: 631-640

50. Imaizumi K, Morihara T, Mori Y, Katayama T, Tsuda M, Furuyama T, Wanaka A, Takeda M, Tohyama M (1999) The cell deathpromoting gene DP5, which interacts with the BCL2 family, is induced during neuronal apoptosis following exposure to amyloid beta protein. J Biol Chem 274:7975-7981

51. Sanz C, Horita M, Fernandez-Luna JL (2002) Fas signaling and blockade of Bcr-Abl kinase induce apoptotic Hrk protein via DREAM inhibition in human leukemia cells. Haematologica 87: 903-907

52. Harris CA, Johnson EM Jr (2001) BH3-only Bcl-2 family members are coordinately regulated by the $\mathrm{JNK}$ pathway and require Bax to induce apoptosis in neurons. J Biol Chem 276:37754-37760 
53. Inohara N, Ding L, Chen S, Núñez G (1997) harakiri, a novel regulator of cell death, encodes a protein that activates apoptosis and interacts selectively with survival-promoting proteins Bcl-2 and Bcl-X(L). EMBO J 16:1686-1694

54. Song ZF, Ji XP, Li XX, Wang SJ, Wang SH, Zhang Y (2008) Inhibition of the activity of poly (ADP-ribose) polymerase reduces heart ischaemia/reperfusion injury via suppressing JNK-mediated AIF translocation. J Cell Mol Med 12:1220-1228

55. Sarszegi Z, Bognar E, Gaszner B, Kónyi A, Gallyas F Jr, Sumegi B, Berente Z (2012) BGP-15, a PARP-inhibitor, prevents imatinibinduced cardiotoxicity by activating Akt and suppressing JNK and p38 MAP kinases. Mol Cell Biochem 365:129-137

56. Virág L, Robaszkiewicz A, Vargas JM, Javier Oliver F (2013) Poly(ADP-ribose) signaling in cell death. Mol Aspects Med. doi: 10.1016/j.mam.2013.01.007

57. Strosznajder JB, Czapski GA, Adamczyk A, Strosznajder RP (2012) Poly(ADP-ribose) polymerase-1 in amyloid beta toxicity and Alzheimer's disease. Mol Neurobiol 46:78-84

58. Strosznajder RP, Czubowicz K, Jesko H, Strosznajder JB (2010) Poly(ADP-ribose) metabolism in brain and its role in ischemia pathology. Mol Neurobiol 41:187-196

59. Strosznajder JB, Cieslik M, Cakala M, Jesko H, Eckert A, Strosznajder RP (2011) Lipoxygenases and poly(ADP-ribose) polymerase in amyloid beta cytotoxicity. Neurochem Res 36:839-848

60. Andrabi SA, Kim NS, Yu SW, Wang H, Koh DW, Sasaki M, Klaus JA, Otsuka T, Zhang Z, Koehler RC, Hurn PD, Poirier GG, Dawson VL, Dawson TM (2006) Poly(ADP-ribose) (PAR) polymer is a death signal. Proc Natl Acad Sci U S A 103:18308-18313

61. Miramar MD, Costantini P, Ravagnan L, Saraiva LM, Haouzi D, Brothers G, Penninger JM, Peleato ML, Kroemer G, Susin SA (2001) NADH oxidase activity of mitochondrial apoptosis-inducing factor. J Biol Chem 276:16391-16398
62. Chinta SJ, Rane A, Yadava N, Andersen JK, Nicholls DG, Polster BM (2009) Reactive oxygen species regulation by AIF- and complex I-depleted brain mitochondria. Free Radic Biol Med 46:939-947

63. Sevrioukova IF (2011) Apoptosis-inducing factor: structure, function, and redox regulation. Antioxid Redox Signal 14:2545-2579

64. Ferreira P, Villanueva R, Cabon L, Susín SA, Medina M (2013) The oxido-reductase activity of the apoptosis inducing factor: a promising pharmacological tool? Curr Pharm Des 19:2628-2636

65. Wang Y, Dawson VL, Dawson TM (2009) Poly(ADP-ribose) signals to mitochondrial AIF: a key event in parthanatos. Exp Neurol 218:193-202

66. Kauppinen TM, Chan WY, Suh SW, Wiggins AK, Huang EJ, Swanson RA (2006) Direct phosphorylation and regulation of poly(ADP-ribose) polymerase-1 by extracellular signal-regulated kinases 1/2. Proc Natl Acad Sci U S A 103:7136-7141

67. Sauer B, Gonska H, Manggau M, Kim DS, Schraut C, SchäferKorting M, Kleuser B (2005) Sphingosine 1-phosphate is involved in cytoprotective actions of calcitriol in human fibroblasts and enhances the intracellular Bcl-2/Bax rheostat. Pharmazie 60:298-304

68. Li QF, Wu CT, Guo Q, Wang H, Wang LS (2008) Sphingosine 1phosphate induces Mcl-1 upregulation and protects multiple myeloma cells against apoptosis. Biochem Biophys Res Commun 371:159-162

69. Avery K, Avery S, Shepherd J, Heath PR, Moore H (2008) Sphingosine-1-phosphate mediates transcriptional regulation of key targets associated with survival, proliferation, and pluripotency in human embryonic stem cells. Stem Cells Dev 17:1195-1205

70. Betito S, Cuvillier O (2006) Regulation by sphingosine 1-phosphate of Bax and Bad activities during apoptosis in a MEK-dependent manner. Biochem Biophys Res Commun 340:1273-1277

71. Nakahara T, Iwase A, Nakamura T, Kondo M, Bayasula KH, Takikawa S, Manabe S, Goto M, Kotani T, Kikkawa F (2012) Sphingosine-1phosphate inhibits $\mathrm{H} 2 \mathrm{O} 2$-induced granulosa cell apoptosis via the PI3K/Akt signaling pathway. Fertil Steril 98:1001-1008 